Original paper doi: 10.5937/ZemBilj1902001B

\title{
The effect of bacterial isolates from rhizosphere soils on wheat and barley seed germination
}

\author{
Aneta V. Buntić ${ }^{1}$, Olivera S. Stajković-Srbinović ${ }^{1}$, Magdalena M. Knežević*¹, Nataša I. \\ Rasulić$^{1}$, Đorđe Ž. Kuzmanović ${ }^{1}$, SuzanaI. Dimitrijević-Branković ${ }^{2}$, Dušica I. Delić ${ }^{1}$ \\ ${ }^{1}$ Institute of Soil Science, Department of Microbiology, Teodora Drajzera 7, 11000, Belgrade,Serbia \\ ${ }^{2}$ Faculty of Technology and Metallurgy, University of Belgrade, Department of Biochemical Engineering and \\ Biotechnology, Karnegijeva 4, 11000 Belgrade, Serbia \\ *Corresponding author: knez.magdalena@gmail.com; magdalena.knezevic@soilinst.rs
}

\begin{abstract}
Soil microorganisms, which are usually found in plant rhizosphere, have a wide spectrum of beneficial effects on the promotion of plant growth. The most comprehensively studied bacteria with these effects belong to the Bacillus genus. In this study, seven Bacillus isolates from Medicago sativa rhizosphere soils were isolated. Plant growth promoting characteristics of these isolates, such as production of indole-3aceticacid, siderophores and hydrogen cyanide were tested. The induction of wheat (Triticum aestivum) and barley (Hordeum jubatum) seed germination was evaluated in vitro. Isolate BMG2 produced the highest indole-3-aceticacid of $24.89 \mu \mathrm{g} / \mathrm{mL}$. The length of roots of barley increased up to $60 \%$, while the length of shoots of barley increased 2.23 times afterapplying isolatesPAZE-6 and BMG1, respectively. In addition, isolates BMG1, BMG2 and PAZE-6 improved germination of both types of seeds and showed ability to produce useful substances such as siderophores and indole-3-acetic acid. Further, these isolates could be used in the production of liquid crop additives that can improve the total yield of cultivated plants, especially barley.
\end{abstract}

Keywords: Bacillus sp., seed germination, indole-3-acetic acid (IAA), siderophores, Triticum aestivum, Hordeum jubatum.

\section{INTRODUCTION}

Plant growth promoting rhizobacteria (PGPR) are a heterogeneous group of bacteria that have the capability of synthesizing plant growth-promoting substances and decrease or prevent the deleterious effects of phytopathogenic microorganisms. They can be found in the rhizosphere, root surfaces and in association with roots, such as in symbiotic association inroot nodule formation. Soil microorganisms are important for agriculture as they promote the circulation of plant nutrients on the one side and reduce the need for chemical fertilizers on the other side 
Original paper doi: 10.5937/ZemBilj1902001B

(Çakmakçi et al. 2007; Yadav et al., 2010). A large number of bacteria including species of Pseudomonas, Azospirillum, Azotobacter, Klebsiella, Enterobacter, Alcaligenes, Arthrobacter, Burkholderia, Bacillus, Rhizobium (Bradyrhizobium, Sinorhizobium) and Serratia have been reported as PGPR to improve plant growth (Yadav et al., 2010; Buntić et al., 2019, Stajkovic et al., 2011, Kumawat et al., 2019). They can improve the quality of plant growth directly and/or indirectly. Directly by the synthesis of phytohormones, vitamins, enzymes, inhibiting plant ethylene synthesis, enhancing stress resistance, improving nutrient uptake, fixing atmospheric nitrogen, solubilising inorganic phosphate, iron and mineralising organic phosphate (Canbolat et al., 2006; Dobbelaere et al., 2003, Çakmakçi et al. 2007). Plant growth benefits due to the addition of PGPR include increases in germination rate, root growth, yield, leaf area, chlorophyll content, nitrogen content, protein content, tolerance to drought, shoot and root weight, and delayed leaf senescence (Dobbelaere et al., 2003; Çakmakçi et al. 2005, 2007). One of the most commonly reported PGPR is Bacillus species. It has range of reported properties, including nitrogen fixation, $\mathrm{P}$ solubilisation, antibiotic and cytokinin production (Hu et al., 2019; Singh et al., 2015; Fira et al., 2018; Dimkic et al., 2015). It is also reported that Bacillus isolates can increase root and shoot growth of wheat (Knezevic et al., 2019). For example, Bacillus megaterium increased grain yield of rice and barley and reduced the required $\mathrm{P}$ fertilization of sugarcane by 25\% (Sundara et al., 2002; Çakmakçi et al. 2007).

The aim of this study was to evaluate the efficiency of novel bacterial isolates from Medicago sativa rhizosphere soils (Bacillus isolates) on induction of wheat (Triticum aestivum) and barley (Hordeum jubatum) germination (in vitro). The length of the roots and shoots, and the relative seed germination index (RSGI) of the seed were calculated. In addition, simple characterization of isolates and quantified indole-3-acetic acid (IAA) production were performed.

\section{MATERIAL AND METHODS}

The bacterial strains used in this research were isolated form rhizosphere soils gathered from local grassland. Soil sample was diluted to $10^{-6}$, and heated on $80^{\circ} \mathrm{C}$ during 15 min to isolate Bacillus spores. The seven obtained isolates(B3, B4, B5, BMG1, BMG2, PAZE-4 and PAZE-6), preliminary characterized as species of Bacillus genus, based on the cell morphology and Gram staining, were grown on Nutrient agar and used for further tests. 
Original paper doi: 10.5937/ZemBilj1902001B

The ability of bacterial isolates to produce siderophores was tested by azurol S (CAS) agar plate assay, as described by Milagres (1999). A loopfull of bacterial culture, previously grown on a nutrient agar, was transferred to the borderline between CAS and NA medium. The inoculated Petri dishes were incubated for 7 days at $28^{\circ} \mathrm{C}$. The change of CAS agar color form blue to yellow was regarded as a positive reaction. The experiment was performed in 3 independent repetitions.

The production of indole-3-acetic acid was tested in a liquid nutrient broth enriched with $0.5 \mathrm{mg} / \mathrm{mL}$ and $2 \mathrm{mg} / \mathrm{mL}$ of tryptophan. Isolates were grown in liquid medium for $24 \mathrm{~h}$ at $28^{\circ} \mathrm{C}$ and centrifuged (13.000 rpm, 5min). After centrifugation, $1 \mathrm{~mL}$ of supernatant was mixed with $2 \mathrm{~mL}$ of Salkowski reagent $\left(0.5 \mathrm{M} \mathrm{FeCl}_{3}\right.$ in $35 \% \mathrm{HCLO}_{4}$ solution $)$ and placed in a dark place during $30 \mathrm{~min}$. Optical density (OD) was recorded at $530 \mathrm{~nm}$ for each sample. The results were expressed as $\mu \mathrm{g} / \mathrm{mL}$ of IAA based on the comparison to the standard curve of auxin solution $(0$, 5, 10, 20, 50, 100 and $120 \mathrm{rpm})$.

The production of Hydrogen cyanide ( $\mathrm{HCN})$ was tested using Cyantesmo paper. Bacterial isolates were streaked on Petri dishes containing a nutrient agar, and pieces of Cyantesmo paper (approximately $2 \mathrm{~cm}$ ) were placed on the inner top of the Petri dish. Plates were incubated for 7 days at $28^{\circ} \mathrm{C}$. The color change of Cyantesmo paper from white to gray was considered asa positive result.

The API-ZYM system (bioMérieux, USA)was applied according to the manufacturer's recommendations. A pure overnight bacterial culture from the nutrient medium was centrifuged. The suspension, with a turbidity of 5-6 McFarland in API Suspension Medium (2 mL), was prepared using precipitate. The inoculum $(65 \mu \mathrm{L})$ was pipetted into each well of the kit, and then the API test strip was covered and incubated for $4.5 \mathrm{~h}$ at $30^{\circ} \mathrm{C}$. After incubation, one drop of reagents "ZymA" and "ZymB" were added to stop the reaction, and the resulting color was developed over $5 \mathrm{~min}$. The development of color was scored as positive reaction.

The ability of bacterial isolates to induce the germination of wheat and barley seeds was tested in vitro in Petri dishes. A sterile filter paper was moistened with $1 \mathrm{~mL}$ of sterile distilled water and placed with 40 wheat or 20 barley seeds in a Petri dish. The control sample consisted of wheat or barley seeds, without any bacterial treatment applied. The test treatment sample was prepared by immersing seeds in overnight bacterial culture. The experiment was performed in 
Original paper doi: 10.5937/ZemBilj1902001B

triplicate. The Petri dishes were placed in a transparent sealed box at room temperature $\left(22^{\circ} \mathrm{C}\right)$ to provide humidity. The results were scored after seven days and expressed by the length of shoots and roots and the relative seed germination (\%) index (RSGI) (Buntić et al., 2017). The percentage of RSGI is expressed by Eq.1:

$$
\operatorname{RSGI}(\%)=\frac{\mathbf{S G}_{\mathbf{s}}}{\mathbf{S G}_{\mathbf{c}}} \times 100
$$

where $\mathrm{SG}_{\mathrm{S}}$ is seeds germination in samples and $\mathrm{SG}_{\mathrm{C}}$ is seeds germination in control.

\section{RESULTS AND DISSCUSION}

The results of CAS agar assay showed that all tested isolates, except B5 and PAZE-6, have the ability to synthesize siderophores (Table 1).

Table 1. Production of siderophores, IAA and HCN by Bacillus isolates

\begin{tabular}{cccc}
\hline Isolate & Siderophores & IAA $(\boldsymbol{\mu g} / \mathbf{m L})^{*}$ & HCN \\
\hline B3 & + & 4.22 & - \\
B4 & ++ & 6.00 & - \\
B5 & - & 0.37 & - \\
BMG1 & + & 3.85 & - \\
BMG2 & + & 24.89 & - \\
PAZE-4 & + & 3.19 & - \\
PAZE-6 & - & 8.67 & \\
\hline
\end{tabular}

*- in the presence of tryptophan $(2 \mathrm{mg} / \mathrm{mL})$

Isolate B4 had the largest halo zone and showed the best potential in the production of siderophores. However, none of the tested isolates could produce HCN. A study conducted by Singh et al. (2015) showed that Bacillusstrains isolated from rhizosphere soil could not produce $\mathrm{HCN}$ and IAA, but they are potent producers of siderophores.

In addition, all tested isolates produced IAA in the presence of tryptophan concentration of $2 \mathrm{mg} / \mathrm{mL}$ (Table 1). However, the production of IAA was low in the presence of $0.5 \mathrm{mg} / \mathrm{mL}$ of tryptophan. Isolate BMG2 showed the highest IAA production of $24.89 \mu \mathrm{g} / \mathrm{mL}$, and was therefore characterized as the most potent producer. Isolates PAZE-6 and B4 also produced significant amounts of IAA, $8.67 \mu \mathrm{g} / \mathrm{mL}$ and $6.00 \mu \mathrm{g} / \mathrm{mL}$, respectively. As all other tested Bacillus isolates showed lower IAA producing ability they could be characterized as weak producers. Research performed by Mohite (2013) also indicated that bacteria isolated from 
Original paper doi: 10.5937/ZemBilj1902001B

rhizosphere soils could be very efficient in the production of plant growth stimulating substances, such as IAA. Furthermore, a research conducted by Djordjevic et al. (2017) indicated that the inoculation of maize seeds with indolacetic acid from Bacillus isolates has direct positive effects on root and shoot growth. Bacillus isolate used in their study had the ability to produce $8,86 \mu \mathrm{g} / \mathrm{mL}$ of IAA, which was similar as in the case of isolate PAZE-6 used in this research (Djordjevic et al., 2017).

Table 2. Isolates characterization (API-ZYM test)

\begin{tabular}{|c|c|c|c|c|c|c|c|}
\hline \multirow[t]{2}{*}{ Enzyme } & \multicolumn{7}{|c|}{ Bacillus isolate } \\
\hline & B3 & B4 & B5 & BMG1 & BMG2 & PAZE-4 & PAZE-6 \\
\hline \multicolumn{8}{|l|}{ Phosphatase: } \\
\hline Alkaline phosphatase & + & - & + & - & - & - & + \\
\hline Acid phosphatase & + & + & + & & + & + & + \\
\hline Naphthol-AS-BI-phosphohydrolase & + & + & + & + & + & + & + \\
\hline \multicolumn{8}{|l|}{ Esterase: } \\
\hline $\mathrm{C} 4$ esterase & - & + & + & + & + & + & + \\
\hline C8 esterase lipase & - & - & + & - & + & + & + \\
\hline C14 lipase & - & - & - & - & - & - & - \\
\hline \multicolumn{8}{|l|}{ Amino peptidase: } \\
\hline Leucine arylamidase & + & + & + & + & + & + & + \\
\hline Valine arylamidase & - & - & - & - & - & + & + \\
\hline Cystinearylamidase & - & - & - & - & - & - & - \\
\hline \multicolumn{8}{|l|}{ Protease: } \\
\hline Trypsin & + & - & + & - & - & - & + \\
\hline$\alpha$-chymotrypsin & + & - & - & + & + & + & - \\
\hline \multicolumn{8}{|l|}{ Glycosyl hydrolase: } \\
\hline$\alpha$-galactosidase & - & + & - & - & - & - & - \\
\hline$\beta$-galactosidase & + & + & - & + & + & + & - \\
\hline$\beta$-glucuronidase & - & - & - & - & - & - & - \\
\hline$\alpha$-glucosidase & + & + & - & - & - & + & - \\
\hline$\beta$-glucosidase & - & - & + & - & - & - & + \\
\hline $\mathrm{N}$-acetyl- $\beta$-glucosaminidase & + & - & + & - & - & - & - \\
\hline$\alpha$-mannosidase & + & + & - & - & - & - & - \\
\hline$\alpha$-fucosidase & - & - & - & - & - & - & - \\
\hline
\end{tabular}

According to API-ZYM test, all seven tested Bacillus isolates, showed the ability to produce various enzymes form phosphatase, esterase, amino peptidase, protease and glycosyl hydrolase groups (Table 2). Isolates B3, B5 and PAZE-6 had the richest enzymatic profile with the ability to produce 10 (B3) and 9 (B5 and PAZE-6) different enzymes. The production of these enzymes could be useful for the indirect promotion of plant growth, especially proteases 
Original paper doi: 10.5937/ZemBilj1902001B

which could improve antagonist effects of PGP bacteria by interacting with the cell walls of plant pathogenic fungi.

The effect of seven Bacillus isolates on T.aestivum and H. jubatum seeds germination and the length of shoot and root are shown on Table 3 and Fig. 1, respectively.

Table 3. Germination of wheat (T.aestivum) and barley (H. jubatum) seeds treated with Bacillus isolates

\begin{tabular}{ccccccccc}
\hline \multirow{2}{*}{ Seeds } & \multicolumn{7}{c}{ RSGI (\%) } \\
\cline { 2 - 8 } & B3 & B4 & B5 & BMG1 & BMG2 & PAZE-4 & PAZE-6 & Control \\
\cline { 2 - 8 } & 90.00 & 85.00 & 95.00 & 100.00 & 100.00 & 95.00 & 100.00 & 95.00 \\
Barley & 85.00 & 95.00 & 95.00 & 97.75 & 97.50 & 95.00 & 97.50 & 95.00 \\
Wheat & 850 &
\end{tabular}

According to the RSGI, all tested bacterial isolates showed goodeffect onT.aestivum and $H$. jubatum seeds germination. However, the lowest seed germination was obtained after applying isolatesB3 and B4 on wheat and barley seeds, respectively. On the contrary, isolates BMG1, BMG2 and PAZE-6 improved the seed germination process (Table 3) in comparison to control. In the literature, there are studies which also confirmed that Bacillus species were capable to improve seed germination including wheat and barley seeds (Hu et al., 2019; Abbasdokht and Gholami, 2010; Yadav et al., 2010; Canbolat et al. 2006).

In addition, all applied Bacillus isolates significantly improved the growth of shoots and roots of barley, recorded over seven days (Figs.1 and 2). The increase in the length of shoot of barley was between 1.39 (PAZE-6) to 1.99 (B3) times and 2.23 (BMG1) times in relation to control (Figs 1 and 2). While, the length of root of barley was increased by $31 \%, 39 \%, 54 \%$, $55 \%$ and $60 \%$ with the applied PAZE-4, B5, BMG2, BMG1 and PAZE-6 respectively. The isolate BMG1 greatly increased the length of shoot and on the same time it contributed to the significant improvement of root length (Fig.1).

On the other hand, isolate B3 improved the growth of shoot and less growth of roots of barley seeds. Canbolat et al. (2006) also reported that Bacillus strains (RC01, RC02, RC03 and M-13) improved the growth both roots and shoots of barley seeds. The strain Bacillus RC01 showed the highest increase in root length of $8.88 \%$ (Canbolat et al. 2006). In addition, Çakmakçi et al. (2007) studied the effect of plant growth promoting rhizobacteria on barley seed using Rhodobactercapsulatus RC04, Paenibacilluspolymyxa RC05, Pseudomonas putida RC06, Bacillus OSU-142, Bacillus M-13, Bacillus megaterium RC01 and Bacillus licheniformis RC02. 
Original paper doi: 10.5937/ZemBilj1902001B

$10.1 \%$. The highest improvement in the length of shoot and root in relation to control sample was obtained by strain Bacillus OSU-142 with values of 5.4\% and 7\%, respectively (Çakmakçi et al. 2007).

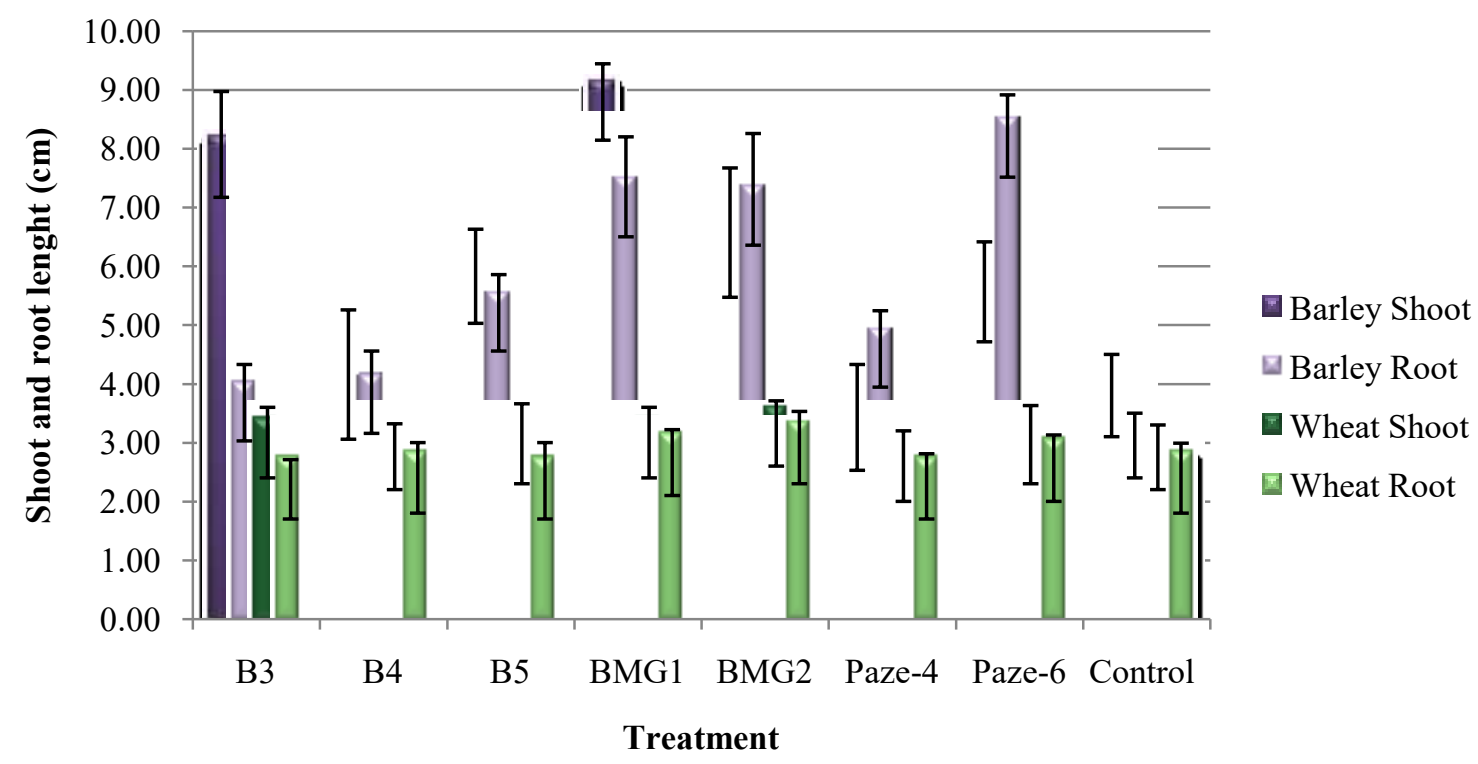

Figure 1. The effect of Bacillus isolates on the length of shoot and root of T.aestivum and $H$. jubatum seeds
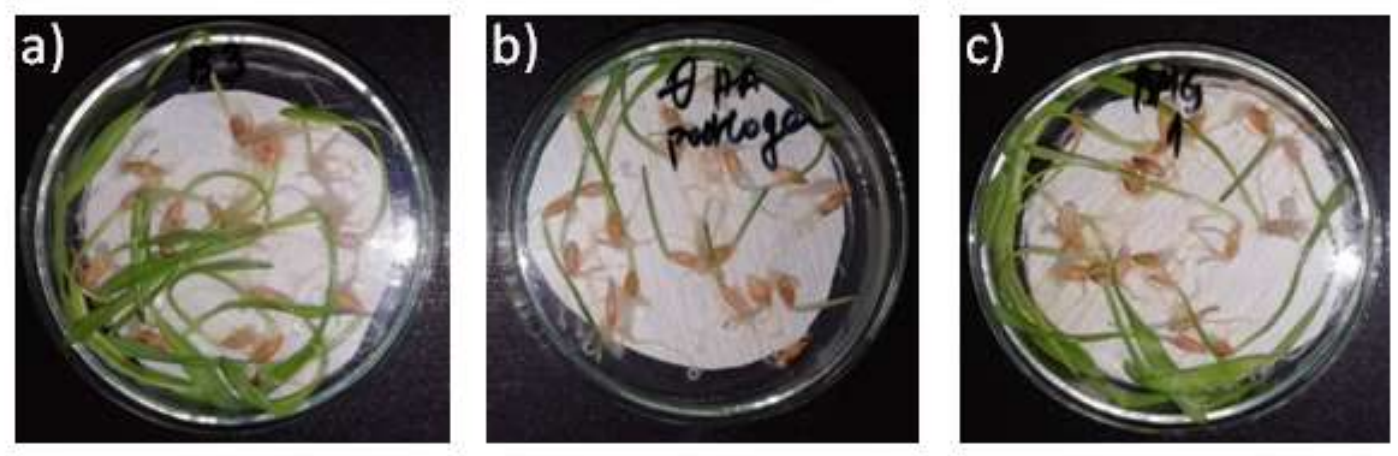

Figure 2. The growth of shoots of H. jubatum seeds treated with B3 (a) and BMG1 isolate (c) and control (b)

However, applied Bacillusisolatesshowed low T.aestivum seeds germination. The highest increase in the length of shoot and root was given by BMG2 and it was $11.2 \%$ and $15.2 \%$ in comparison to control, respectively (Fig.1). Taking into account the types of seeds, the isolate BMG2, with very good RSGI and good results of increasing the length of shoot and root for both seeds, can be considered as a good plant growth promoting bacteria forwheat and barley. In addition, this isolate showed ability for the production of IAA $(24.89 \mu \mathrm{g} / \mathrm{mL})$ and siderophores. 
Original paper doi: 10.5937/ZemBilj1902001B

Growth promotion may be due to other mechanisms such as production of plant growth promoting hormones in the rhizosphere and other PGP activities. These abilities depend on the availability of precursors for their production by microorganisms and their uptake by plant (Yadav et al., 2010).

\section{CONCLUSION}

Bacillus isolates BMG1, BMG2 and PAZE-6showed the strongest potential in the inductionof barley and wheat seed germination. All tested isolates improved the growth of shoots and roots of barely. None of the isolates has the ability to produce HCN. Isolates BMG2 and PAZE-6 produced the highest amount of IAA, while B4 showed the best potential in the production of siderophores. Based on the obtained results it can be considered that isolates BMG1, BMG2 and PAZE-6 could be used as PGP agents.

\section{ACKNOWLEDGEMENTS}

The financial support for this research given by the Ministry of Education, Science and Technological Development of the Republic of Serbia under the project TR 31035 and TR 37006 is gratefully acknowledged.

\section{REFERENCES}

AbbasdokhtH, and Gholami A. 2010: The Effect of Seed Inoculation (Pseudomonas putida + Bacilluslentus) and Different Levels of Fertilizers on Yield and Yield Components of Wheat (Triticumaestivum L.) Cultivars.International Journal of Agricultural and Biosystems Engineering, 4(8): 678-682.

Buntić AV, Pavlović MD, Antonović DG, Šiler-Marinković SS, Dimitrijević-Branković SI. 2017: A treatment of wastewater containing basic dyes by the use of new strain Streptomyces microflavus CKS6. Journal of cleaner production, 148, 347-354.

Buntić AV, Stajković-Srbinović OS, Knežević MM, Kuzmanović ĐŽ, Rasulić NV, Delić DI. 2019: Development of liquid rhizobial inoculants and pre-inoculation of alfalfa seeds. Archives of Biological Sciences, doi.org/10.2298/ABS181008062B. 
Original paper doi: 10.5937/ZemBilj1902001B

Canbolat MY, Bilen S, Çakmakçı R, Şahin F, Aydın A. 2006: Effect of plant growth-promoting bacteria and soil compaction on barley seedling growth, nutrient uptake, soil properties and rhizosphere microflora. Biology and fertility of soils, 42(4), 350-357.

Dimkic I, Stevic T, Beric T, Nikolic I, Janakiev T, Fira D, Stankovic S. 2015: In vitro antifungal potential of Bacillus spp.: Isolates as biocontrol agents. Lekovite sirovine, 35: 163-180.

Djordjevic S, Stanojevic D, Vidovic M, Mandic V, Trajkovic I. 2017: The use of bacterial indol3-acetic acid (IAA) for reduce of chemical fertilizers doses. Chemical Industry, 71(3): 195200.

Dobbelaere S, Vanderleyden J, Yaacov O. 2003: Plant growth-promoting effects of diazotrophs in the rhizosphere. Critical Reviews in Plant Science, 22: 107-149.

Fira D, Dimkić I, Berić T, Lozo J, Stanković S. 2018: Biological control of plant pathogens by Bacillus species. Journal of Biotechnology, 285: 44-55.

Hu Q, Liu R, Liu J. 2019: Effects of Bacillus subtilis QM3 on Germination and Antioxidant Enzymes Activities of Wheat Seeds under Salt Stress. OALib, 06(03): 1-9.

Knežević M., Buntić A., Stajković-Srbinović O., Mihajlovski K., Rasulić N., Stanković S., Delić D. 2019: Antagonistic effect of soil-borne Bacillus isolates against Fusarium infection and induction of wheat seed germination, 1st International Symposium: „Modern Trends in Agricultural Production and Environmental Protection", Tivat, Montenegro 2-5. july 2019, Proceedings: 183-196.

Kumawat K, Sharma P, Sirari A, Singh I. Gill B, Singh U, Saharan K. 2019: Synergism of Pseudomonas aeruginosa (LSE-2) nodule endophyte with Bradyrhizobium sp. (LSBR-3) for improving plant growth, nutrient acquisition and soil health in soybean. World Journal of Microbiology and Biotechnology, 35(3): 35-47.

Milagres AM, Machuca A, Napoleão D. 1999: Detection of siderophore production from several fungi and bacteria by a modification of chrome azurol S (CAS) agar plate assay. Journal of Microbiological Methods, 37(1): 1-6.

Mohite B. 2013: Isolation and characterization of indole-3-acetic acid (IAA) producing bacteria from rhizospheric soil and its effect on plant growth. Journal of Soil Science and Plant Nutrition: 638-649.

Singh R, Pathak B, Fulekar MH. 2015: Characterization of PGP Traits by Heavy Metals Tolerant Pseudomonas putida and Bacillus safensisStrain Isolated from Rhizospheric Zone of Weed 
Original paper doi: 10.5937/ZemBilj1902001B

(Phyllanthusurinaria) and its efficiency in $\mathrm{Cd}$ and $\mathrm{Pb}$ Removal. International Journal of Current Microbiology and Applied Sciences, 4(7): 954-975.

Stajković O, Delić D, Jošić D, Kuzmanović Đ, Rasulić N, Knežević-Vukčević J. 2011: Improvement of common bean growth by co-inoculation with Rhizobium and plant growthpromoting bacteria. Romanian Biotechnological Letters, 16(1): 5919-5926.

Sundara B, Natarajan V, Hari K. 2002: Influence of phosphorus solubilizing bacteria on the changes in soil available phosphorus and sugarcane and sugar yield. Field Crop Research, 77: 43-49.

Yadav J, Verma JP, Tiwari, KN. 2010: Effect of plant growth promoting rhizobacteria on seed germination and plant growth chickpea (Cicer arietinum L.) under in vitro conditions. Biological Forum, 2(2): 15-18.

Çakmakçi R, Donmez F, Aydın A, Fiahin F. 2006: Growth promotion of plants by plant growthpromoting rhizobacteria under greenhouse and two different field soil conditions. Soil Biology and Biochemistry, 38: 1482-1487.

Çakmakçi R, Mesude FD, Ümmügülsüm E. 2007: The effect of plant growth promoting rhizobacteria on barley seedling growth, nutrient uptake, some soil properties, and bacterial counts. Turkish Journal of Agriculture and Forestry, 31.3: 189-199. 
Original paper doi: 10.5937/ZemBilj1902001B

\title{
Uticaj bakterijskih izolata iz zemljištarizosfere na indukciju klijavosti semena pšenice i ječma
}

\author{
Aneta V. Buntić ${ }^{1}$, Olivera S. Stajković-Srbinović ${ }^{1}$, Magdalena M. Knežević*¹, Nataša I. \\ Rasulić ${ }^{1}$, Djordje Ž. Kuzmanović ${ }^{1}$, SuzanaI. Dimitrijević-Branković ${ }^{2}$ Dušica I. Delić ${ }^{1}$ \\ ${ }^{1}$ Institute of Soil Science, Department of Microbiology, Teodora Drajzera 7, 11000, Belgrade,Serbia \\ ${ }^{2}$ Faculty of Technology and Metallurgy, University of Belgrade, Department of Biochemical Engineering and \\ Biotechnology, Karnegijeva 4, 11000 Belgrade, Serbia \\ ${ }^{*}$ Corresponding author:knez.magdalena@gmail.com; magdalena.knezevic@soilinst.rs
}

IZVOD: Zemljišne bakterije iz rizosfere korena biljaka najčešće imaju širok spektar pozitivnog dejstva na biljke I mogu poboljšati njhiov rast. Vrste roda Bacillus jedne su od najistraživanijih bakterija koje mogu doprinositi poboljšanju rasta biljaka. U ovom radu je izolovano sedam Bacillus izolata iz rizosfere lucerke (Medicago sativa). Ispitivana je sposobnost produkcije jedinjenja kao što su vodonik-cijanid, indol-3-sirćetna kiselina I siderofore. Procenjena je I sposobnost indukcije klijavosti na semena pšenice (Triticum aestivum) I ječma (Hordeum jubatum). Izolat BMG2 je proizveo najviše indol-3-sirćetne kiseline $(28.89 \mu \mathrm{g} / \mathrm{mL})$. Dužina korenčića je povećana za $60 \%$, dok je dužina izdanka uvećana 2.23 puta primenom izolata PAZE-6 i BMG1. Pored toga, izolati BMG1, BMG2 i PAZE-6, su poboljšali klijavost obe vrste semena I pokazali sposobnost da proizvedu korisne supstance kao što su sideroforei indol-3sirćetna kiselina. Na dalje bi ovi izolati mogli da se koriste u proizvodnji tečnih aditiva koji bi povećali prinos kultivisanih biljaka, a posebno ječma.

Ključne reči: Bacillus sp., klijavost semena, indol-3-sirćetna kiselina (IAA), siderofore, Triticum aestivum, Hordeum jubatum. 